\title{
IDENTIFIKASI TANAH LEMPUNG KOTA PADANG BERDASARKAN UJI KLASIFIKASI TEKNIK DAN UJI BATAS-BATAS KONSISTENSI ATTERBERG
}

\author{
Rina Yuliet ${ }^{1}$
}

\begin{abstract}
ABSTRAK
Tanah-tanah yang banyak mengandung lempung mengalami perubahan volume ketika kadar air berubah. Pengurangan kadar air menyebabkan lempung menyusut dan sebaliknya bila kadar air bertambah lempung mengembang. Perubahan volume tanah yang besar dapat membahayakan bangunan sehingga perlu penanganan yang serius. Penelitian ini bertujuan untuk mengetahui potensi mengembang tanah lempung di kota Padang dan untuk mengetahui derajat pengembangannya. Metode yang digunakan untuk identifikasi tanah lempung adalah uji klasifikasi teknik dan uji batas-batas konsistensi Atterbergh. Berdasarkan uji yang dilakukan secara keseluruhan terlihat bahwa dari 9 kriteria yang diberikan untuk masing-masing daerah hanya $24,07 \%$ dari kriteria tersebut yang menyatakan derajat pengembangan rendah, $16,67 \%$ derajat pengembangan sedang, $33,33 \%$ derajat pengembangan tinggi dan $25,93 \%$ menyatakan derajat pengembangan sangat tinggi. Jika suatu tanah diklasifikasikan sebagai tanah dengan potensi mengembang yang rendah, maka konstruksi standar bisa digunakan. Namun demikian jika tanah memiliki potensi mengembang yang sedang dan tinggi maka tindakan pencegahan perlu diambil.
\end{abstract}

Kata Kunci : Tanah lempung mengembang, uji klasifikasi teknik, derajat pengembangan.

\section{PENDAHULUAN}

\subsection{Latar Belakang}

Tanah mengembang (expansive soil) adalah tanah yang memiliki ciri-ciri kembang susut besar, mengebang pada musim hujan dan menyusut pada musim kemarau. Besarnya pengembangan/ penyusutan tidak merata dari suatu titik ke titik lainnya sehingga menimbulkan differential movement. Banyak negara-negara di dunia yang menghadapi masalah tanah mengembang, seperti Amerika Serikat, Canada, Australia, Afrika Selatan dan Israel. Kerugian yang diakibatkan oleh tanah mengembang diantaranya adalah :

- Penggelembungan (heave) dan retak (cracking) pada permukaan jalan raya.

- Kelebihan tegangan lateral pada dinding penahan tanah.

- Heave dan buckling pada slab lantai.

- Heave dan buckling pada dinding kanal.

- Berkurangnya daya dukung dan kuat geser tanah.

Penyusutan (shrinking) sebagian besar diakibatan oleh peristiwa kapiler. Pada musim kemarau terjadi pengeringan, kadar air berkurang diikuti oleh kenaikan tegangan efektif sehingga volume tanah menyusut. Pengembangan (swelling) mekanismenya lebih kompleks dibandingkan penyusutan (Kormonik dan David, 1969).

Pengaruh susut pada tanah-tanah berbutir halus menjadi masalah penting dalam masalah teknik. Retak akibat susut dapat muncul secara lokal, jika tekanan kapiler melampaui kohesi atau kuat tarik

\footnotetext{
${ }^{1}$ Staf Pengajar Jurusan Teknik Sipil Fakultas Teknik Universitas Andalas, e-mail: rina@ft.unand.ac.id
} 
tanah. Retak-retak ini merupakan bagian dari makrostruktur lempung dan merupkan zona-zona lemah yang secara signifikan mereduksi kekuatan massa tanah secara keseluruhan, sehingga dapat mempengaruhi stabilitas lereng lempung dan kapasitas dukung fondasi.

Retak akibat pengeringan permukaan yang sering dijumpai pada lempung lunak dapat berpengaruh jelek, misalnya pada strukur perkerasan jalan yang dibangun diatasnya. Susut dan retak disebabkan oleh penguapan permukaan saat musim panas, penurunan muka air tanah dan isapan akar tumbuhtumbuhan. Ketika musim hujan, tanah mendapatkan air sehingga volume tanah bertambah dan tanah mengembang. Perubahan volume akibat proses kembang susut sering merusakan bangunan gedung ringan dan perkerasan jalan raya.

Pada umumnya pengerasan jalan atau pembangunan gedung dilaksanakan pada musim panas, sehingga tanah permukaan pada kondisi kering. Bangunan yang menutup tanah mencegah penguapan sehingga tanah di bawah bangunan bertambah kadar airnya oleh akibat kapiler yang menyebabkan tanah lempung mengembang. Jika tekanan pengembangan (swelling pressure), maka permukaan tanah akan naik dan akibatnya bangunan yang ada di atasnya akan rusak.

Di alam, kadar air sangat berfluktuasi terutama di dekat permukaan tanah. Hal ini karena di dekat permukaan tanah dipengaruhi oleh penguapan dan isap akar tumbuhan. Hal yang penting dalam mengevaluasi masalah pengembangan tanah adalah kedalaman zona aktif. Kadar air di bawah zona aktif dianggap selalu konstan, sehingga di bawah zona aktif tidak ada pengembangan tanah. Pada proses kembang susut tanah tidak sepenuhnya kembali ke posisi semula. Lempung menjadi overconsolidated dan berkurang kemudah-mampatannya akibat dari bertambahnya tegangan efektif oleh tekanan kapiler.

Pengembangan merupakan proses yang agak komplek dibanding dengan penyusutan (Yong dan Warketin, 1975). Besar dan nilai pengembangan bergantung pada banyaknya mineral lempung di dalam tanah dan kadar air awal. Tanah dengan susunan random cendrung lebih mudah mengembang daripada tanah dengan susunan teratur. Gangguan tanah atau pembentukan kembali tanah lempung dapat menambah sifat mudah mengembang. Kation-kation monovalent dalam lempung (contohnya sodium montmorillonite) akan mengembang lebih besar dari pada lempung divalent (contohnya kalsium montmorillonite). Sementasi dan bahan-bahan organik cendrung mengurangi pengembangan. Untuk memprediksi potensi mengembang tanah lempung di kota Padang, perlu dilakukan identifikasi tanah lempung berdasarkan uji klasifikasi teknik dan uji batasbatas konsistensi Atterberg.

\subsection{Tujuan dan Manfaat Penelitian}

Tujuan dari penelitian ini adalah untuk mengetahui potensi mengembang tanah lempung di kota Padang dan untuk mengetahui derajat pengembangannya dengan uji klasifikasi teknik dan uji batas-batas konsistensi Atterberg.

Manfaat penelitian ini adalah diharapkan akan membantu untuk lebih mengerti bagaimana perilaku mengembang tanah lempung di kota Padang sehingga dapat diketahui bagaimana cara penanggulangannya.

\subsection{Ruang Lingkup Masalah}

Data yang digunakan untuk mengidentifikasi tanah lempung adalah data sekunder yang diambil dari beberapa pengujian yang dilakukan di Laboratorium Mekanika Tanah Universitas Andalas, Padang. Uji minerologi tanah dan kimia tanah tidak dilakukan untuk mengidentifikasi tanah lempung mengembang. 


\section{DASAR TEORI}

\subsection{Identifikasi Tanah Lempung Mengembang}

Ada beberapa metode yang digunakan untuk mengetahui tanah lempung mengembang, yaitu :

\subsubsection{Uji Klasifikasi Teknik}

Hasil pengujian indeks properties tanah dapat digunakan untuk mengidentifikasi dan mengklasifikasikan tanah lempung mengembang. Indeks plastisitas dan sifat perubahan volume tanah berhubungan dengan jumlah partikel yang berukuran lebih kecil dari $0.001 \mathrm{~mm}$, yaitu yang sifatnya tergantung dari gaya permukaan dan bukan dari gaya gravitasi. Skempton mengemukakan rumus dari parameter aktifitas $(A C)$ sebagai berikut :

$$
\text { Aktifitas }(A c)=\frac{\text { Indeks Plastis }}{c-10}
$$

dimana :

$$
\begin{array}{ll}
C & : \text { Presentase fraksi lempung }<0,002 \\
A c>1,25 & : \text { tanah bersifat aktif dan ekspansif } \\
0,75>A C>1,25 & : \text { tanah digolongkan normal } \\
A c<0,75 & : \text { digolongkan tidak aktif }
\end{array}
$$

Dalam tabel di bawah ini dapat dilihat hubungan aktivitas dan kandungan mineral tanah lempung.

Tabel 1. Hubungan Mineral Lempung dengan Aktivitas (Skempton,1953 dan Mitchel, 1976)

\begin{tabular}{|l|c|}
\hline \multicolumn{1}{|c|}{ Mineral } & Activity \\
\hline Na-Montmorillonite & $4-7$ \\
Ca-Montmorillonite & 1.5 \\
Illite & $0.5-1.3$ \\
Kaolinite & $0.3-0.5$ \\
Halloysite (dehydrated) & 0.5 \\
Halloysite (hydrated) & 0.1 \\
Attapulgite & $0.5-1.2$ \\
Allophane & $0.5-1.2$ \\
Mica & 0.2 \\
Cacite & 0.2 \\
Quartz & 0 \\
\hline
\end{tabular}

Tabel 2. Klasifikasi Tanah Ekspansif menurut USBR (Holtz \& Gibbs. 1956)

\begin{tabular}{|c|c|c|c|c|}
\hline \multicolumn{3}{|c|}{ Data Indeks Properties } & $\begin{array}{c}\text { Pengembangan } \\
\text { akibat Tekanan 6.9 kPa } \\
(\mathbf{\%})\end{array}$ & $\begin{array}{c}\text { Potensi } \\
\text { Pengembangan }\end{array}$ \\
\hline $\begin{array}{c}\mathbf{\%} \text { Koloid } \\
(<\mathbf{0 0 0 1} \mathbf{~ m m})\end{array}$ & $\begin{array}{c}\text { Indeks } \\
\text { Plastisitas (\%) }\end{array}$ & $\begin{array}{c}\text { Batas } \\
\text { Susut (\%) }\end{array}$ & $>30$ & Sangat tinggi \\
\hline$>28$ & $>35$ & $<11$ & $20-30$ & Tinggi \\
\hline $20-13$ & $25-41$ & $7-12$ & $10-20$ & Sedang \\
\hline $13-23$ & $15-28$ & $10-16$ & $<10$ & Rendah \\
\hline$<15$ & $<18$ & $>15$ & & \\
\hline
\end{tabular}

Tabel 3. Klasifikasi Tanah Ekspansif berdasarkan Batas Susut menurut Altmeyer (1955)

\begin{tabular}{|c|c|c|c|}
\hline Linear Shrinkage & Batas Susut, SL (\%) & Kemungkinan Mengembang (\%) & Derajat Pengembangan \\
\hline$<5$ & $>12$ & $<0,5$ & Tidak kritis \\
\hline $5-8$ & $10-12$ & $0,5-1,5$ & Sedang \\
\hline$>8$ & $<10$ & $<1,5$ & Kritis \\
\hline
\end{tabular}




\subsubsection{Uji Minerologi}

Ada beberapa cara yang dapat dikerjakan untuk mengetahui kandungan minerologi tanah, yang paling terkenal adalah metoda difraksi sinar X. Tapi disamping itu ada metoda lain diantaranya analisa diferensial termal, analisa kimia, analisa mikroskop electron dan Dye adsorption.

a). Difraksi Sinar X (X-Ray Difraction)

Metoda ini digunakan untuk menentukan perbandingan dari berbagai mineral yang terdapat pada koloid lempung, yaitu dengan membandingkan intensitas dari garis difraksi dari berbagai mineral terhadap garis bahan standar. Mineral berbeda dengan kristal dan akan memberikan difraksi sinar X yang berbeda. Biasanya pola struktur kristal yang umum sudah ditabelkan. Analisis kwantitatif mungkin, biarpun relative tetapi persen banyak masing-masing mineral bisa didapat. Identifikasi mineral tanah lempung dilakukan dengan bantuan difraktometer sinar $\mathrm{X}$ (XRD). Terlebih dahulu dibuat preparatnya dengan mengendapkan fraksi lempung pada lempeng keramik, setelah siap, preparat tersebut dijenuhkan dengan $\mathrm{Mg}_{2}{ }^{+}, \mathrm{Mg}^{+}+$glycerol, $\mathrm{K}^{+}$dan $\mathrm{K}^{+}$dipanaskan pada suhu $550^{\circ} \mathrm{C}$ selama 1 jam. Prinsip analisis XRD adalah merekam dan memvisualisasikan pantulan sinar $\mathrm{X}$ dari kisi-kisi kristal dalam bentuk grafik. Grafik tersebut kemudian dianalisis, terdiri atas mineral lempung apa saja dan relative komposisinya. Analisis mineral lempung juga dapat dilakukan dengan contoh berupa serbuk halus (powder). Analisis ini biasanya dilakukan untuk menganalisis pupuk, mineral standar atau mineral primer yang sulit diidentifikasi dengan mikroskop.

b). Analisis Penurunan Panas (Differential Thermal Analysis)

Cara ini baik digunakan untuk memeriksa material yang mengalami perubahan karakteristik akibat panas. Suatu contoh tanah yang tidak diketahui komposisi mineral dipanaskan sampai ratusan derajat Celcius. Yang dicari adalah suatu perubahan struktur akibat temperatur. Kemudian dibandingkan dengan mineral yang telah diketahui sifat-sifatnya.

c). Analisa Kimia

Analisa kimia dapat digunakan sebagai pelengkap untuk metoda difraksi sinar X. Pada mineral montmorillonite, analisa kimia dapat digunakan untuk menentukan kandungan isomorphon.

d). Mikroskop Elektron (Electron Microscope Resolution)

Kegunaan metoda ini adalah untuk menentukan komposisi mineral, textur dan struktur internal. Dari metoda ini juga dapat dilihat perbedaan dalam karakteristik marphologinya.

e). Penyerapan Terbilas (Dye Absorption)

Bahan celup dan bahan reagen lainnya akan menimbulkan warna tertentu bila diserap oleh lempung, dapat juga digunakan untuk mengidentifikasi lempung.

\subsubsection{Uji Batas-Batas Konsistensi Atterberg}

a). Kriteria Raman (1967)

Tabel 4. Kriteria Tanah Ekspansif berdasarkan PI dan menurut Raman (1967)

\begin{tabular}{|c|c|c|}
\hline Indeks Plastisitas, PI (\%) & Indeks Penyusutan (\%) & Derajat Pengembangan \\
\hline$<12$ & $<15$ & Rendah \\
\hline $12-23$ & $15-30$ & Sedang \\
\hline $23-30$ & $30-40$ & Tinggi \\
\hline 30 & $>40$ & Sangat Tinggi \\
\hline
\end{tabular}

b). Kriteria Snethen (1977)

Tabel 5. Klasifikasi Potensial Pengembangan menurut Snethen et.al, (1977)

\begin{tabular}{|c|c|c|c|}
\hline Batas Cair (\%) & PI (\%) & Potensi Mengembang (\%) & Klasifikasi Potensi Mengembang \\
\hline$>60$ & $>35$ & $>1,5$ & Tinggi \\
\hline $50-60$ & $25-35$ & $0,5-1,5$ & Sedang \\
\hline$<50$ & $<25$ & $<0,5$ & Rendah \\
\hline
\end{tabular}


c). Kriteria Chen (1965)

Tabel 6. Klasifikasi berdasarkan Lolos Saringan 200, LL \& SPT menurut Chen (1965)

\begin{tabular}{|c|c|c|c|c|}
\hline \multicolumn{3}{|c|}{ Data Laboratorium dan Lapangan } & \multirow{2}{*}{$\begin{array}{l}\text { Kemungkinan } \\
\text { Ekspansi (\%) }\end{array}$} & \multirow{2}{*}{$\begin{array}{c}\text { Potensi } \\
\text { Pengembangan }\end{array}$} \\
\hline $\begin{array}{c}\text { \% Lolos Saringan } \\
\text { No. } 200 \\
\end{array}$ & $\begin{array}{c}\text { Batas Cair, LL } \\
(\%)\end{array}$ & N-SPT & & \\
\hline$>95$ & $>60$ & $>30$ & $>10$ & Sangat tinggi \\
\hline $60-95$ & $40-60$ & $20-30$ & $3-10$ & Tinggi \\
\hline $30-60$ & $30-40$ & $10-20$ & $1-5$ & Sedang \\
\hline$<30$ & $<30$ & $<10$ & $<1$ & Rendah \\
\hline
\end{tabular}

d). Kriteria Chen (1988)

Tabel 7. Kriteria Pengembangan berdasarkan PI menurut Chen (1988)

\begin{tabular}{|c|c|}
\hline Indeks Plastisitas, PI (\%) & Derajat Pengembangan \\
\hline $0-15$ & Rendah \\
\hline $10-35$ & Sedang \\
\hline $20-35$ & Tingi \\
\hline$>35$ & Sangat tinggi \\
\hline
\end{tabular}

e). Kriteria Seed

Tabel 8. Klasifikasi Derajat Ekspansi (Seed et al., 1962)

\begin{tabular}{|c|c|}
\hline Potensi Pengembangan (\%) & Derajat Pengembangan \\
\hline $0-1,5$ & Rendah \\
\hline $1,5-5$ & Sedang \\
\hline $5-25$ & Tingi \\
\hline$>25$ & Sangat tinggi \\
\hline
\end{tabular}

f). Kriteria William (1958)

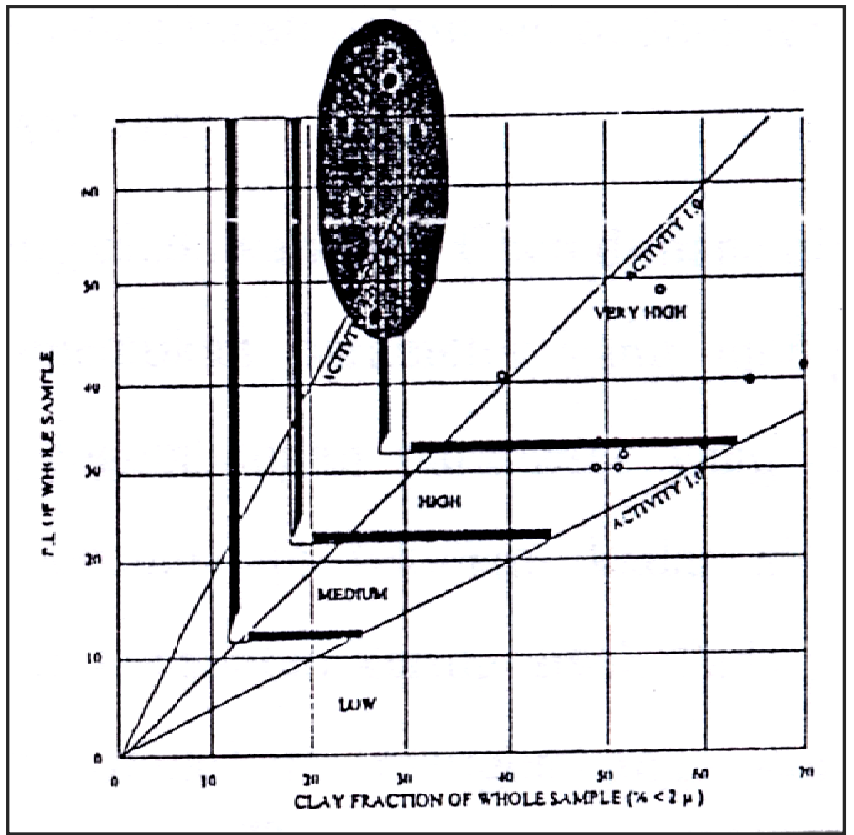

Gambar 1. Klasifikasi Potensi Pengembangan Tanah Lempung (Sumber : Potential Ekspansif of Soil, William 1958-1959) 
Partikel lempung mempunyai muatan listrik negatif. Dalam suatu kristal yang ideal, muatanmuatan negatif dan positif seimbang. Akan tetapi, akibat subtitusi isomorf dan kontiniutas perpecahan susunannya, terjadi muatan negatif pada permukaan partikel lempung. Untuk mengimbangi permukaan muatan negatif tersebut, partikel lempung menarik ion muatan positif (kation) dari garam yang ada di dalam air pori. Hal ini disebut pertukaran ion-ion. Kation-kation dapat disusun dalam urutan kekuatan daya tarik-menariknya, sebagai berikut :

$$
\mathrm{Al}^{3+}>\mathrm{Ca}^{2+}>\mathrm{Mg}^{2+}>\mathrm{NH}^{4+}>\mathrm{K}^{+}>\mathrm{H}^{+}>\mathrm{Na}^{+}>\mathrm{Li}^{+}
$$

Urutan tersebut memberikan arti bahwa ion $\mathrm{Al}^{3+}$ dapat mengganti $\mathrm{Ca}^{2+}, \mathrm{Ca}^{2+}$ dapat mengganti $\mathrm{Na}^{+}$ dan seterusnya. Proses ini disebut dengan pertukaran kation, sebagai contoh :

$$
\mathrm{N}_{\mathrm{a} \text { (lempung) }}+\mathrm{C}_{\mathrm{a}} \mathrm{Cl}_{2} \rightarrow \mathrm{C}_{\mathrm{a} \text { (lempung) }}+\mathrm{N}_{\mathrm{a}} \mathrm{Cl}
$$

\subsection{Penyebaran Lempung Montmorillonit di Indonesia}

Montmorillonite dikenal di Indonesia sejak dimulainya aktivitas minyak bumi yaitu kira-kira 100 tahun yang lampau. Bentonite adalah istilah yang digunakan dalam dunia perdagangan untuk sejenis lempung yang mengandung mineral montmorillonite. Nama bentonite ini pertama kali dipergunakan pada tahun 1896 oleh Knight yaitu sejenis lempung yang sangat plastis (koloid) yang terdapat pada formasi Benton, rock creeck, Wyoming, Amerika Serikat. Nama ini diusulkan sebagai pengganti dari nama sebelumnya yaitu soap clay (1873) Taylorite (1888) dan masih banyak nama lain yang dikenal.

Pada tahun 1960, Gibson mendefinisikan bentonite sebagai mineral lempung yang terdiri dari $85 \%$ montmorillonite yang mempunyai rumus kimia $\left(\mathrm{AL}_{2} \mathrm{O}_{3} \cdot 4 \mathrm{SiO}_{2} \times \mathrm{H}_{2} \mathrm{O}\right)$. Nama montmorillonite ini berasal dari jenis lempung plastis yang ditemukan di daerah Montmorillon, Perancis pada tahun 1947. Berdasarkan tipenya bentonite dapat dibagi menjadi 2 yaitu :

a. Tipe Wyoming (Na-Bentonite)

Jenis bentonite tipe Wyoming mempunyai kemampuan mengembang hingga mencapai delapan kali bila dicelupkan kedalam air. Tipe bentonite ini banyak menyerap air dengan pengembangan yang besar dan tetap terdispersi beberapa waktu dalam air. Dalam keadaan kering barwarna putih atau krem, sebaliknya pada keadaan basah dan terkena sinar matahari akan berwarna mengkilap. Perbandingan soda dan kapur tinggi. Suspensi koloidal bentonit Wyoming mempunyai $\mathrm{pH}: 8.5-9.8$, tidak dapat diaktifkan, posisi pertukaran ion sama-sama diduduki oleh ion-ion sodium $(\mathrm{Na})$

b. Tipe Sub Bentonite (Mg, Ca-Bentonite)

Tipe bentonit ini memiliki kemampuan mengambang hingga mencapai 1.5 kali apabila dicelupkan kedalam air. Bentonite tipe ini tetap terdispersi di dalam air, perbandingan kandungan $\mathrm{Na}$ dan $\mathrm{Ca}$ rendah, suspensi memiliki p : 4 - 7. Posisi pertukaran ion lebih banyak diduduki oleh ion-ion magnesium dan kalsium. Dalam keadaan kering bersifat rapid slakin, berwarna abu-abu, biru, kuning dan coklat. Sebagian besar endapan bentonite di Indonesia digolongkan Ca-Bentonit (Kalsium Bentonite).

Lokasi endapan bentonite (lempung montmorillonite) di Indonesia tersebar di Pulau Jawa, Pulau Sumatera, sebagian Pulau Kalimantan dan Pulau Sulawesi, yaitu :

a. Lokasi endapan bentonite di Pulau Jawa

- Jawa Barat

- Jawa Tengah

- Jawa Timur
: Kab. Rangkasbitung, Leuwiliang, Bogor, Sukabumi, Ciamis, Tasikmalaya, Purwakarta, Karawang

: Nanggulan dan tanjung Harjo, Boyolali, Wonosegara, G. Pentur

: Pacitan, Trenggelek, Blitar, Malang 
b. Lokasi Endapan bentonite di Pulau Sumatera
- Sumatera Utara
: Simalungun, Karo, Pangkalan Berandan
- Sumatera Selatan
: Liot, Lahat
- Lampung
: Bandar Lampung
- Jambi
: Sorolangun, Bangko
c. Lokasi endapan bentonite di daerah Barito Kalimantan
d. Lokasi endapan bentonite di daerah Manado Sulawesi Utara

\subsection{Pondasi pada Tanah Mengembang}

Ada beberapa lempung plastis yang mengembang ketika air ditambahkan dan kemudian akan menyusut jika kehilangan air. Konstruksi pondasi pada tanah lempung ini mengalami gaya angkat (uplift) yang besar disebabkan oleh pengembangan (swelling). Gaya-gaya ini akan megakibatkan heave, retak dan patah pada pondasi bangunan serta dasar slab. Tanah mengembang menutupi sebagian besar Amerika Serikat, Amerika Selatan, Afrika, Australia dan India. Di Amerika Serikat tanah lempung mendominasi di daerah Texas, Oklahoma dan lembah Missouri. Pada umumnya potensi mengembangnya tanah lempung yang memiliki batas cair (LL) $>40$ dan batas plastis (PL) $>15$.

Jika suatu tanah diklasifikasikan sebagai tanah dengan potensi mengembang yang rendah, maka konstruksi standard bisa digunakan. Namun demikian jika tanah memiliki potensi mengembang yang sedang dan tinggi maka tindakan pencegahan perlu diambil terlebih dahulu. Berikut ini adalah cara-cara yang perlu dilakukan, yaitu :

- Mengganti tanah ekspansif yang berada di bawah pondasi

Ketika tanah ekspansif berada pada kondisi sedang dengan kedalaman yang rendah dari muka tanah maka tanah expansive dapat dibuang dan diganti dengan tanah yang lebih baik, kemudian dipadatkan.

- Merubah sifat-sifat asli tanah ekspansif dengan kontrol pemadatan, prewetting, instalasi moisture barriers dan stabilisasi secara kimia. Stabilisasi tanah mengembang dengan pressure injection adalah teknik stabilisasi dengan menyuntikan campuran kapur atau kapur-campur fly ash kedalam tanah, biasanya sampai kedalaman 4-5 m dan kadang-kadang lebih dalam untuk menutupi zona aktif. Tergantung pada kondisi tanah di lapangan, injeksi tunggal atau injeksi multiple, dapat direncanakan seperti pada Gambar 2.
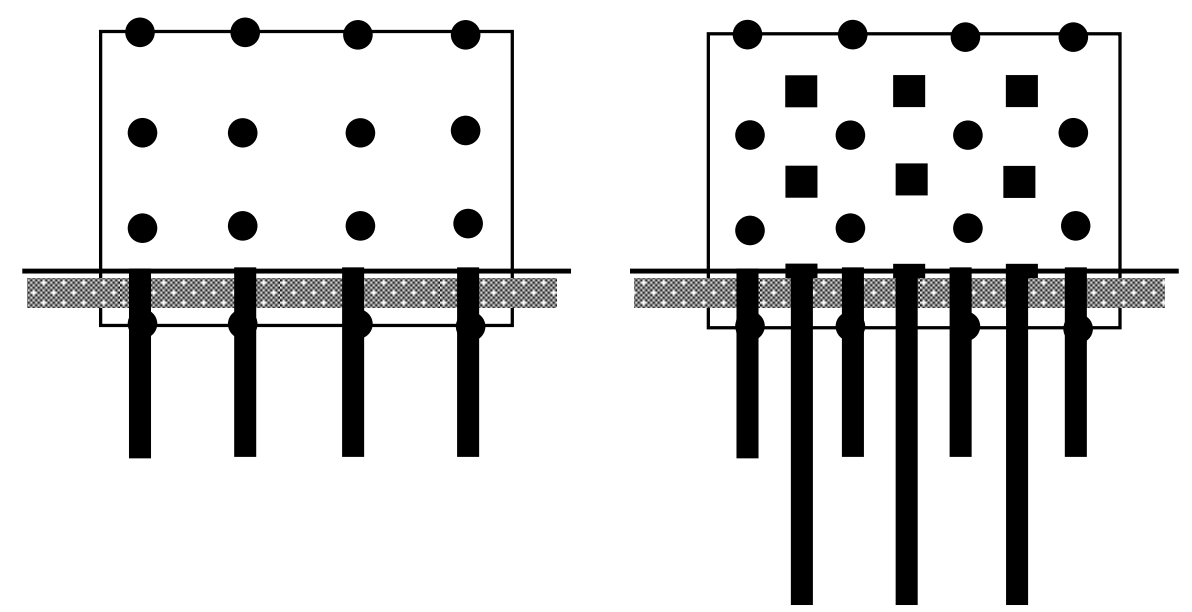

Gambar 2. Rencana Injeksi Campuran Kapur untuk suatu Telapak Gedung 
- Struktur perkuatan untuk menahan heave, pembangunan struktur yang cukup fleksibel untuk menahan penurunan tanah tanpa keruntuhan atau pembangunan isolated (pemisah) pondasi dalam di bawah kedalaman dari zona aktif. Gambar 4 menunjukan skema diagram pondasi tiang, dimana dasar dari tiang (piers) harus diletakan di bawah zona aktif dari tanah mengembang.

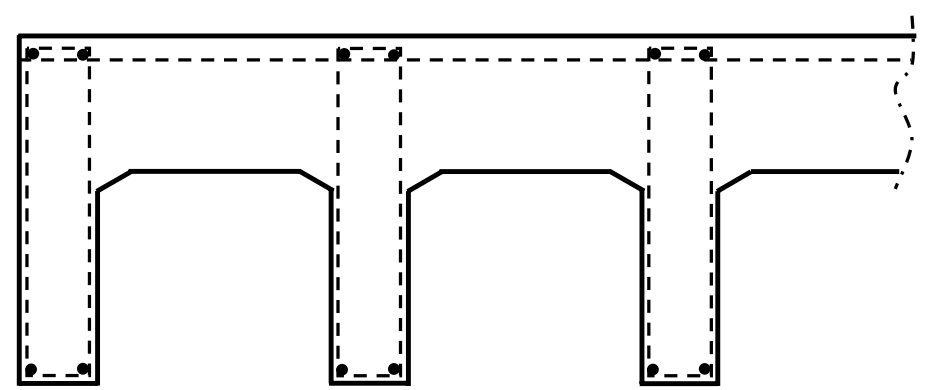

Gambar 3. Waffle Slab

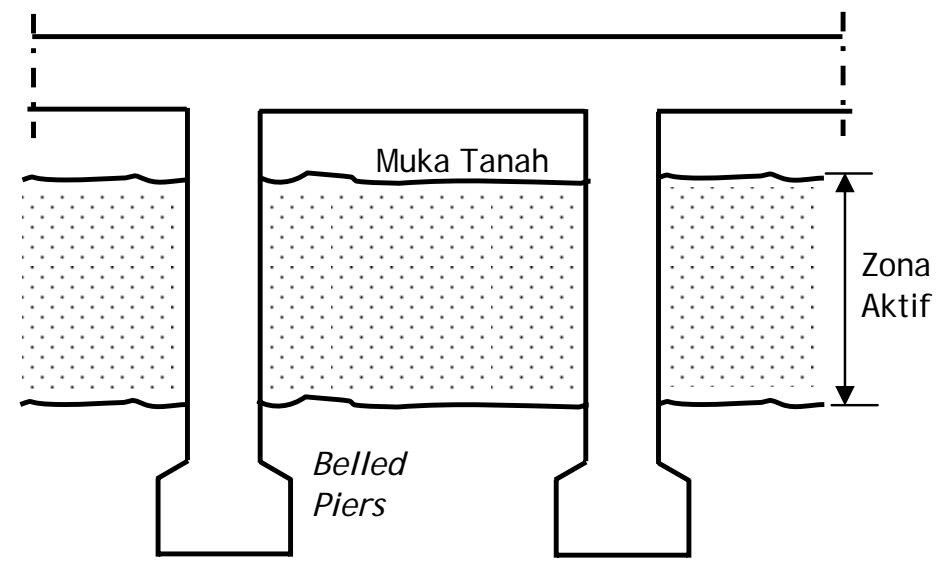

(a)

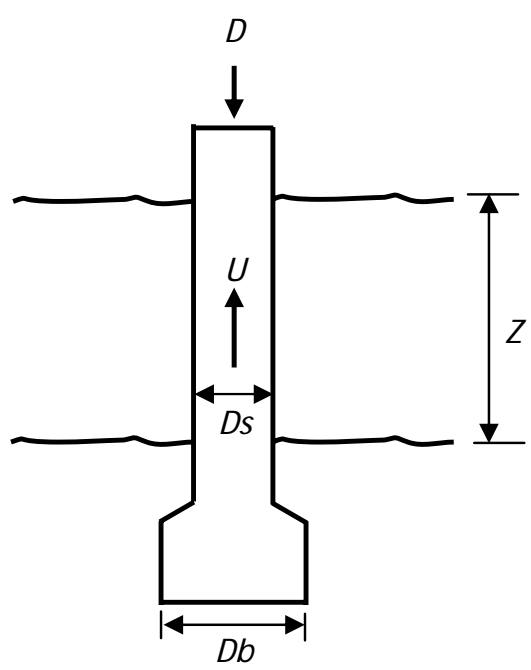

(b)

Gambar 4. (a). Konstruksi Tiang Belled dan Balok Tingkat , (b). Definisi Parameter 


\section{ANALISA DAN PEMBAHASAN}

\subsection{Hasil Uji Batas-Batas Konsistensi Tanah dan Analisa Saringan}

Hasil uji batas-batas konsistensi tanah dan analisa saringan terhadap sampel tanah yang diambil di 12 daerah di kota Padang, dapat dilihat pada Tabel 9 dan Tabel 10 berikut ini.

Tabel 9. Hasil Uji Indeks Propertis Tanah

\begin{tabular}{|c|l|c|r|r|c|}
\hline \multirow{2}{*}{ No. Lokasi } & \multicolumn{2}{|c|}{ Uji Batas-Batas Atterberg } & \multirow{2}{*}{$\begin{array}{c}\text { Analisa Saringan } \\
\text { (\% Lolos \#200) }\end{array}$} \\
\cline { 3 - 5 } & & LL & \multicolumn{1}{c|}{ PL } & \multicolumn{1}{c|}{ PI } & 64,37 \\
\hline 1. & Kampung Dalam & 60,90 & 40,94 & 19,96 & 29,20 \\
\hline 2. & Indarung & 68,00 & 49,48 & 18,62 & 44,40 \\
\hline 3. & Anduring & 36,83 & 22,22 & 14,60 & 25,17 \\
\hline 4. & Pasar Ambacang & 36,67 & 30,11 & 8,56 & 62,23 \\
\hline 5. & Gunung Pangilun & 84,50 & 44,24 & 37,26 & 53,83 \\
\hline 6. & Aie Pacah & 88,00 & 49,30 & 38,67 & 41,91 \\
\hline 7. & By Pass (Simpang Taruko) & 65,00 & 38,80 & 28,21 & 54,93 \\
\hline 8. & Kampus UPI & 88,00 & 35,32 & 52,68 & 24,76 \\
\hline 9. & Kampus Fak. Teknik Unand & 77,30 & 53,68 & 23,62 & 96,73 \\
\hline 10. & Lambung Bukit & 82,84 & 56,29 & 26,55 & 90,61 \\
\hline 11. & Kampus Fak. Kedokteran Unand & 100,00 & 51,34 & 49,17 & 95,53 \\
\hline 12. & Limau Manih & 119,37 & 51,54 & 67,83 & \\
\hline
\end{tabular}

\subsection{Hasil Identifikasi Tanah Lempung Padang berdasarkan Uji Klasifikasi Teknik}

Tabel 10. Hasil Uji Identifikasi Tanah Lempung Kota Padang berdasarkan Nilai Activity

\begin{tabular}{|c|l|c|c|c|}
\hline No. & \multicolumn{1}{|c|}{ Lokasi } & Activity $(\mathbf{A c})$ & $\begin{array}{c}\text { Potensi } \\
\text { Mengembang }\end{array}$ & $\begin{array}{c}\text { Menurut USBR } \\
\text { (Tabel 1) }\end{array}$ \\
\hline 1. & Kampung Dalam & 0,367114 & Tidak aktif & Sedang \\
\hline 2. & Indarung & 0,969792 & Normal & Sedang \\
\hline 3. & Anduring & 0,424419 & Tidak aktif & Rendah \\
\hline 4. & Pasar Ambacang & 0,564272 & Tidak aktif & Rendah \\
\hline 5. & Gunung Pangilun & 0,713383 & Tidak aktif & Sangat tinggi \\
\hline 6. & Aie Pacah & 0,882272 & Normal & Sangat tinggi \\
\hline 7. & By Pass (Simpang Taruko) & 0,884049 & Normal & Tinggi \\
\hline 8. & Kampus UPI & 1,172491 & Normal & Sangat tinggi \\
\hline 9. & Kampus Fak. Teknik Unand & 1,600271 & Ekspansif & Sedang \\
\hline 10. & Lambung Bukit & 0,306122 & Tidak aktif & Tinggi \\
\hline 11. & Kampus Fak. Kedokteran Unand & 0,609974 & Tidak aktif & Sangat tinggi \\
\hline 12. & Limau Manih & 0,793055 & Tidak aktif & Sangat tinggi \\
\hline
\end{tabular}




\subsection{Hasil Uji Identifikasi Tanah Lempung Padang berdasarkan Uji Batas-Batas Konsistensi Atterberg}

Tabel 11. Hasil Uji Identifikasi menurut Raman, Snethen, Chen, William

\begin{tabular}{|c|c|c|c|c|c|c|c|c|}
\hline No. & Lokasi & $\begin{array}{c}\text { Raman } \\
\text { PI } \\
\text { (Tabel 4) }\end{array}$ & \begin{tabular}{|c|}
$\begin{array}{c}\text { Snethen } \\
\text { LL } \\
\text { (Tabel 5) }\end{array}$ \\
\end{tabular} & $\begin{array}{c}\text { Snethen, } \\
\text { PI } \\
\text { (Tabel 5) }\end{array}$ & \begin{tabular}{|c|} 
Chen, \\
\%lolos \#200 \\
(Tabel 6) \\
\end{tabular} & \begin{tabular}{|c} 
Chen, \\
LL \\
(Tabel 6)
\end{tabular} & \begin{tabular}{|c|} 
Chen \\
PI \\
(Tabel 7) \\
\end{tabular} & \begin{tabular}{|c|} 
William, \\
PI vs \\
$\%$ lolos \#200
\end{tabular} \\
\hline 1. & Kampung Dalam & Sedang & Tinggi & Rendah & Tinggi & $\begin{array}{l}\text { Sangat } \\
\text { Tinggi }\end{array}$ & Sedang & Rendah \\
\hline 2. & Indarung & Sedang & Tinggi & Rendah & Rendah & $\begin{array}{l}\text { Sangat } \\
\text { Tinggi }\end{array}$ & Sedang & Sedang \\
\hline 3. & Anduring & Sedang & Rendah & Rendah & Sedang & Sedang & Rendah & Rendah \\
\hline 4. & Pasar Ambacang & Rendah & Rendah & Rendah & Rendah & Sedang & Rendah & Rendah \\
\hline 5. & Gunung Pangilun & $\begin{array}{l}\text { Sangat } \\
\text { Tinggi } \\
\end{array}$ & Tinggi & Tinggi & Tinggi & Tinggi & $\begin{array}{l}\text { Sangat } \\
\text { Tinggi } \\
\end{array}$ & Sngat Tinggi \\
\hline 6. & Aie Pacah & $\begin{array}{l}\text { Sangat } \\
\text { Tinggi }\end{array}$ & Tinggi & Tinggi & Tinggi & Tinggi & $\begin{array}{l}\text { Sangat } \\
\text { Tinggi }\end{array}$ & Sangat Tinggi \\
\hline 7. & $\begin{array}{l}\text { By Pass (Simpang } \\
\text { Taruko) }\end{array}$ & $\begin{array}{l}\text { Sangat } \\
\text { Tinggi } \\
\end{array}$ & Tinggi & Sedang & Rendah & Tinggi & Tinggi & Tinggi \\
\hline 8. & Kampus UPI & $\begin{array}{l}\text { Sangat } \\
\text { Tinggi }\end{array}$ & Tinggi & Tinggi & Tinggi & Tinggi & $\begin{array}{l}\text { Sangat } \\
\text { Tinggi }\end{array}$ & Sangat Tinggi \\
\hline 9. & $\begin{array}{l}\text { Kampus Fak. } \\
\text { Teknik Unand }\end{array}$ & Tinggi & Tinggi & Rendah & Rendah & Tinggi & Tinggi & Tinggi \\
\hline 10. & Lambung Bukit & Tinggi & Tinggi & Sedang & $\begin{array}{l}\text { Sangat } \\
\text { Tinggi } \\
\end{array}$ & Tinggi & Tinggi & Tinggi \\
\hline 11. & \begin{tabular}{|l|} 
Kampus Fak. \\
Kedokteran Unand \\
\end{tabular} & $\begin{array}{c}\text { Sangat } \\
\text { Tingi } \\
\end{array}$ & Tinggi & Tinggi & $\begin{array}{l}\text { Sangat } \\
\text { Tinggi } \\
\end{array}$ & $\begin{array}{l}\text { Sangat } \\
\text { Tinggi } \\
\end{array}$ & $\begin{array}{l}\text { Sangat } \\
\text { Tinggi } \\
\end{array}$ & Sangat Tinggi \\
\hline 12. & Limau Manih & $\begin{array}{l}\text { Sangat } \\
\text { Tinggi }\end{array}$ & Tinggi & Tinggi & $\begin{array}{l}\text { Sangat } \\
\text { Tinggi }\end{array}$ & $\begin{array}{l}\text { Sangat } \\
\text { Tinggi }\end{array}$ & $\begin{array}{l}\text { Sangat } \\
\text { Tinggi }\end{array}$ & Sangat Tinggi \\
\hline
\end{tabular}

Tabel 12. Hasil Uji Identifikasi Tanah Lempung berdasarkan Persentase Derajat Pengembangan pada Masing-Masing Daerah

\begin{tabular}{|c|l|c|c|c|c|}
\hline \multirow{2}{*}{ No Lokasi } & \multicolumn{4}{|c|}{ Derajat pengembangan } \\
\cline { 3 - 6 } & & Rendah & Sedang & Tinggi & Sangat Tinggi \\
\cline { 3 - 6 } & & $\%$ & $\%$ & $\%$ & $\%$ \\
\hline 1 & Kampung Dalam & 33 & 33 & 22 & 11 \\
\hline 2 & Indarung & 22 & 56 & 11 & 11 \\
\hline 3 & Anduring & 67 & 33 & 0 & 0 \\
\hline 4 & Pasar Ambacang & 89 & 11 & 0 & 0 \\
\hline 5 & Gunung Pangilun & 11 & 0 & 44 & 44 \\
\hline 6 & Aie Pacah & 0 & 11 & 44 & 44 \\
\hline 7 & By Pass (Simp. Taruko) & 11 & 22 & 56 & 11 \\
\hline 8 & Kampus UPI & 0 & 11 & 44 & 44 \\
\hline 9 & Kampus F. Teknik Unand & 22 & 11 & 67 & 0 \\
\hline 10 & Lambung Bukit & 11 & 11 & 67 & 11 \\
\hline 11 & Kampus Kedokteran Unand & 11 & 0 & 22 & 67 \\
\hline 12 & Limau Manih & 11 & 0 & 22 & 67 \\
\hline
\end{tabular}


Dari Tabel 12 terlihat bahwa ada 2 daerah yang memiliki persentase derajat mengembang rendah dan sedang, yaitu Anduring dan Pasar Ambacang. Serta 10 daerah lainya memiliki derajat mengembang dari tinggi ke sangat tinggi.

Tabel 13. Rekapitulasi Hasil Uji Identifikasi Tanah Lempung Berdasarkan Derajat Pengembangan

Dari Tabel 13 berdasarkan uji klasifikasi teknik dan uji batas-batas konsistensi Atterberg yang dilakukan di beberapa daerah di kota Padang, secara keseluruhan terlihat bahwa dari 9 kriteria yang diberikan untuk masing-masing daerah hanya $24,07 \%$ dari kriteria tersebut yang menyatakan derajat pengembangan rendah, $16,67 \%$ derajat pengembangan sedang, 33,33\% derajat pengembangan tinggi dan $25,93 \%$ menyatakan derajat pengembangan sangat tinggi.

\section{KESIMPULAN}

\subsection{Kesimpulan}

1. Berdasarkan uji klasifikasi teknik dan uji batas-batas konsistensi Atterbergh terdapat 2 daerah yang memiliki persentase potensi mengembang rendah dan sedang, yaitu Anduring dan Pasar Ambacang serta 10 daerah lainya memiliki derajat mengembang dari tinggi ke sangat tinggi.

2. Secara keseluruhan terlihat bahwa dari 9 kriteria yang digunakan untuk mengidentifikasi tanah lempung mengembang di masing-masing daerah hanya $24,07 \%$ dari kriteria tersebut yang menyatakan derajat pengembangan rendah, $16,67 \%$ derajat pengembangan sedang, 33,33\% derajat pengembangan tinggi dan $25,93 \%$ menyatakan derajat pengembangan sangat tinggi.

\subsection{Saran}

Untuk meyakinkan bahwa ke 12 daerah tersebut memiliki potensi mengembang maka perlu dilakukan pegujian lebih lanjut yaitu :

- Uji potensi mengembang di laboratorium sehingga diketahui persen pengembangan tanah. 
- Uji kimia tanah dan minerologi dengan X-Ray difraksi sehingga diketahui kandungan mineral yang ada dalam tanah lempung di masing-masing daerah tersebut. Jika hasil pengujian mengindikasikan adanya mineral Montmorillonite maka baru bisa dikatakan bahwa tanah lempung memiliki potensi mengembang.

\section{DAFTAR PUSTAKA}

Braja M. Das., (1994), "Principles of Foundation Engineering”, Second Edition, PWS-KENT Publishing Company, Boston, page 596-680.

Hary Christadi Hardiyatmo, (2006), Mekanika Tanah 1, Gadjah Mada University Press.

Masyhur Irsyam, (1993), ”Tanah Mengembang, Mekanisme dan Penanggulangan”, Departemen Teknik Sipil, ITB, Bandung.

Rina Yuliet, (2001), "Studi Perilaku Mengembang dengan Metoda ASTM D4546-90 (A, B, C) dan Kekuatan Geser pada Lempung Montmorillonite Karangnunggal”, Thesis, ITB, Bandung.

Suhardjito Pradoto, (1990), "Bahan Pengajaran Perilaku Tanah", Laboratorium Geoteknik PAU Ilmu Rekayasa, ITB, Bandung.

http://elisa.ugm.ac.id/files/cahyonoagus/2jXCfyXq/KOLOID\%20TANAH.ppt

ftp://ftp.dot.state.tx.us/pub/txdot-info/rti/psr/3930-s.pdf 